Original Research Paper

\title{
Pembentukan Karakter Demokratis Melalui Pelaksanaan Metode Pembelajaran Kooperatif tipe Number Head Together pada Siswa Kelas XI SMK Negeri 1 Kota Bima
}

\author{
Mahardin $^{\text {*, }}$ Ahmad Fauzan', Muliati2*, Nurmawadah Rahmah ${ }^{2}$ \\ ${ }^{1}$ Guru PPKN SMK Negeri 1 Kota Bima \\ ${ }^{2}$ Pendidikan Pancasila dan Kewarganegaraan FKIP Universitas Mataram
}

https://doi.org/10.29303/jpmpi.v3i2.1342

Sitasi: Mahardin., Fauzan, A., Muliadi \& Rahmah, N. (2022). Pembentukan Karakter Demokratis Melalui Pelaksanaan Metode Pembelajaran Kooperatif tipe Number Head Together pada Siswa Kelas XI SMK Negeri 1 Kota Bima. Jurnal Pengabdian Magister Pendidikan IPA, 5(1)

\section{Article history}

Received: 11 Januari 2022

Revised: 01 Februari 2022

Accepted: 07 Februari 2022

*Corresponding Author:

Muliati, Pendidikan

Pancasila dan

Kewarganegaraan FKIP

Universitas Mataram

Mataram, Indonesia;

Email:

muliati9567@gmail.com
Abstrak: Karakter demokratis merupakan sebuah cara yang timbul dari diri seseorang untuk berfikir, bersikap, dan bertindak menghargai hak dan kewajiban orang lain. Di Indonesia sendiri menghargai hak dan kewajiban orang lain merupakan suatu hal yang paling penting, dengan sikap ini akan tercermin pribadi seseorang sebagai warga negara yang baik dan taat pada aturan negaranya. Hak dan kewajiban warga negara sudah tertera jelas dalam UUD 1945 pada pasal 26, 27, 28 dan 30. Hak dan Kewajiban merupakan sesuatu yang tidak dapat dipisahkan, seorang warga negara harus melaksanakan hak dan kewajibannya serta harus menghargai hak dan kewajiban orang lain. Tujuan dilakukannya penelitian ini adalah untuk mengetahui pembentukan karakter demokratis di lingkungan kelas melalui pelaksanaan metode pembelajaran NHT (Number Head Together) pada siswa kelas XI di SMKN 1 Kota Bima. Karakter demokratis sangat diharapkan tumbuh dalam diri siswa, agar sejak dini siswa dapat menjadi seorang warga negara yang baik dan sadar akan pentingnya hak dan kewajiban. Penelitian ini menunjukan hasil bahwa : 1) Semua siswa dan siswi menjadi lebih siap dalam belajar, 2) Siswa akan berdiskusi dengan sungguh- sungguh, 3) Hasil belajar akademik struktural bertujuan untuk meningkatkan kinerja siswa dalam tugas- tugas akademik, 4) Pengakuan adanya keberagaman, ini bertujuan agar siswa dapat menerima temantemannya yang mempunyai berbagai latar belakang, 5) Pengembangan keterampilan sosial, ini bertujuan untuk mengembangkan keterampilan sosial siswa. Keterampilan yang di maksud antara lain berbagai tugas, aktif bertanya, menghargai pendapat orang lain, mau menjelaskan ide atau pendapat, bekerja sama dalam kelompok dan sebagainnya, dan 6) Pemahaman siswa lebih mendalam, meningkatkan kebaikan budi pekerti, kepekaan dan toleransi serta hasil belajar lebih tinggi.

Keywords: Karakter Demokratis, Metode Pembelajaran Number Head Together (NHT) 


\section{Pendahuluan}

Karakter merupakan hal yang berkaitan dengan kepribadian seseorang. Menurut KKBI arti dari karakter adalah tabiat, akhlak yang membedakan diri seseorang dengan orang lain. menurut Wynne dalam bahwa ada dua pengertian tentang karakter, pertama karakter menunjukan bagaimana seseorang bertingkah laku, kedua istilah karakter erat kaitannya dengan "personality". Menurut Kusuma (2007) dalam (Juliardi, n.d.) Pendidikan karakter merupakan bentuk kegiatan manusia yang di dalamnya terdapat suatu tindakan yang mendidik diperuntukkan bagi generasi selanjutnya. Tujuan pendidikan karakter adalah untuk membentuk penyempurnaan diri individu secara terus-menerus dan melatih kemampuan diri demi menuju kearah hidup yang lebih baik

Menurut Amirullah (2015), "keluarga merupakan tempat pendidikan pertama dan utama bagi seseorang". Pendidikan dalam keluarga sangat berperan dalam mengembangkan watak, karakter, dan kepribadian seseorang, oleh karena itu, pendidikan karakter dalam keluarga perlu diupayakan secara serius. Selain pentingnya pembentukan karakter seorang anak di lingkungan keluarga, pembentukan karakter seorang anak juga penting pada lingkungan sosial, contohnya pengaruh teman pergaulan terhadap pembentukan karakter baik atau buruk. Jika seorang anak bergaul dan berteman dengan seseorang yang suka bertawuran, minum minuman keras ataupun hal-hal negatif lainnya, maka dapat memberikan pengaruh negatif. Selain di lingkungan keluarga dan lingkungan sosial, karakter seseorang juga dapat terbentuk di lingkungan pendidikan, Pemerintah telah mengupayakan adanya pengembangan karakter-karakter yang ingin dicapai. Langkah paling strategis pemerintah dalam mengembangkan karakter adalah melalui dunia pendidikan.

Kementerian Pendidikan Nasional merumuskan 18 nilai-nilai karakter yang ditanamkan dalam diri siswa sebagai upaya membangun karakter bangsa. 18 nilai tersebut antara lain, religius, jujur, toleransi, disiplin, kerja keras, kreatif, mandiri, demokratis, rasa ingin tahu, semangat kebangsaan, cinta tanah air, menghargai prestasi, bersahabat/berkomunikatif, cinta damai, gemar membaca, peduli lingkungan, peduli sosial, dan tanggung jawab. Pengembangan karakter melalui pendidikan karakter di sekolah dapat diterapkan melalui berbagai hal di dalam lingkungan pendidikan, mulai dari sistem sekolah, pembelajaran, dan melalui kegiatan ekstrakurikuler.

Karakter demokratis merupakan satu dari 18 karakter yang dirumuskan oleh Kementerian Pendidikan Nasional. Menurut (Ilham Muhammad, 2018) Demokratis merupakan sebuah cara berpikir, bersikap, dan bertindak yang yang menilai sama hak dan kewajiban dirinya dengan orang lain. Sikap demokratis juga dapat dikatakan sebagai pandangan hidup seseorang untuk mengutamakan persamaan hak dan kewajiban yang sama bagi semua warga Negara.

Menurut (Saputri Isnaini, n.d.) Demokratis adalah suatu cara mendidik yang aktif, dinamis dan terarah yang berusaha mengembangkan setiap bakat yang dimiliki anak untuk kemajuan perkembangannya. Pola ini menempatkan anak selaku individu sebagai faktor utama dan terpenting dalam pembinaan, sehingga karakter demokratis adalah suatu cara berperpikir atau berperilaku yang terarah untuk mewujudkan pribadi yang baik dan mampu menghargai perbedaan serta mampu menjalankan setiap kewajiban-kewajibanya.

Karakter demokratis sangat penting ada pada setiap diri siswa karena dengan adanya karakter demokratis siswa akan mampu bersosialisasi dengan masyarakat. Dalam bermasyarakat sangat dibutuhkan rasa toleransi, mandiri, tanggung jawab sehingga karakter demokratis harus dibangun pada siswa melalui kegiatan belajar mengajar.

Pembelajaran kooperatif (cooperative learning) merupakan model pembelajaran dengan cara siswa belajar dan bekerja dalam kelompok-kelompok kecil secara kolaboratif yang anggotanya terdiri dari empat hingga lima orang siswa dengan struktur kelompok yang bersifat heterogen. Konsep heterogen disini adalah struktur kelompok yang memiliki perbedaan latar belakang kemampuan akademik, perbedaan jenis kelamin dan perbedaan ras. Hal ini diterapkan untuk melatih siswa menerima perbedaan dan pekerjaan dengan teman yang berbeda latar belakangnya. Model pembelajaan kooperatif merupakan model pembelajaran yang banyak digunakan dan menjadi perhatian serta dianjurkan oleh para ahli pendidikan. Hal ini dikarenakan berdasarkan hasil penelitian yang dilakukan Slavin (1995) yang dikutip oleh Nurdyansyah (2016) dinyatakan bahwa 
a. Pengunaan pembelajaran kooperatif dapat meningkatkan prestasi belajar siswa dan sekaligus dapat meningkatkan hubungan sosial, menumbuhkan sikap toleransi, dan menghargai pendapat orng lain.

b. Pembelajaran kooperatif dapat memenuhi kebutuhan siswa dalam berfikir kritis, memecahkan masalah, dan mengintergrasikan pengetahuan dengan pengalaman. Dengan alasan tersebut, strategi pembelajaran kooperatif diharapkan mampu meningkatkan kualitas pembelajaran.

Metode pembelajaran kooperatif yang akan diterapkan dalam penelitian ini, yaitu dengan menggunakan metode NHT. Menurut Rahayu (2006) Number Head Together (NHT) adalah suatu Model pembelajaran yang lebih mengedepankan kepada aktivitas siswa dalam mencari, mengolah, dan melaporkan informasi dari berbagai sumber yang akhirnya dipresentasikan di depan kelas

\section{Metode}

Penelitian ini dilakukan di SMKN 1 Kota Bima pada tanggal 1 November 2021. Metode yang digunakan dalam penelitian ini adalah menggunakan metode pembelajaran tipe NHT (Number Head Together) dengan pendekatan kualitatif yaitu pendekatan penelitian tanpa menggunakan angka statistik tetapi dengan pemaparan secara deskriptif yaitu berusaha mendeskripsikan suatu gejala, peristiwa, kejadian yang terjadi di saat sekarang, dimana peneliti berusaha mengamati peristiwa dan kejadian yang terjadi pada saat kegiatan belajar mengajar berlangsung yang menjadi fokus perhatiannya untuk kemudian dijabarkan.

Subjek pada penelitian ini adalah siswa kelas XI UPW (Usaha Perjalanan Wisata), sampel sekolah di pilih berdasarkan tempat peneliti enjalankan kegiatan PLP (Pengenalan Lapangan Persekolahan). Sebelum melakukan penelitian adapun hal - hal yang dipersiapkan antara lain :

1. Konsultasi dengan guru mata pelajaran

Agar penelitian melalui kegiatan belajar mengajar dapat berjalan dengan lancar maka sebelum peneliti memasuki ruangan kelas mengajar terlebih dahulu melakukan konsultasi dengan guru mata pelajaran PPKn mengenai hal-hal yang harus dipersiapkan seperti RPP (Rencana Pelaksanaan Pembelajaran), maupun materi pembelajaran.

2. Menyiapkan materi

Penelitian ini dilakukan melalui metode pembelajaran NHT (Number Head Together) pada mata pelajaran PPKn. Materi pembelajaran yang berhubungan dengam pembentukan karakter demokratis adalah mengenai hak dan kewajiban asasi manusia. Melalui pembelajaran materi ini dan di gunakannya metode pembelajaran NHT melatih dan menumbuhkan karakter siswa untuk menghargai hak dan kewajiban orang lain.

\section{Hasil dan Pembahasan}

Pembentukan Karakter Demokratis Siswa Melalui Kegiatan Pembelajaran di SMK Negeri 1 Kota Bima, mulai ditanamkan dalam mata pelajaran Pendidikan Pancasila dan Kewarganegaraan sebagai upaya pembentukan karakter demokratis cukup bervariatif dan di sesuaikan dengan kebutuhan masing-masing siswa. Dalam pelaksanaan pembelajaran guru melaksanakan pembelajaran sesuai dengan kompetensi dasar yang dilaksanakan secara runtut sesuai materi.

Lahirnya pendidikan karakter bisa

dikatakan sebagai sebuah usaha untuk menghidupkan spiritual yang ideal. Tujuan utama dari pendidikan karakter adalah untuk membentuk karakter itu sendiri, karena karakter merupakan suatu evaluasi seorang pribadi atau individu serta karakter pun dapat memberi kesatuan atas kekuatan dalam mengambil sikap di setiap situasi. Pendidikan karakter pun dapat dijadikan sebagai strategi untuk mengatasi pengalaman yang selalu berubah sehingga mampu membentuk identitas yang kokoh dari setiap individu. Dalam hal ini dapat dilihat bahwa tujuan pendidikan karakter ialah untuk membentuk sikap yang dapat membawa kita kearah kemajuan tanpa harus bertentangan dengan norma yang berlaku.

Pendidikan karakter pun dijadikan sebagai wahana sosialisasi karakter yang patut dimiliki setiap individu agar menjadikan mereka sebagai individu yang bermanfaat seluas-luasnya bagi lingkungan sekitar.

Pendidikan demokrasi memfokuskan individu untuk menjadi pribadi yang demokratis 
maka dibutuhkan upaya melalui pembentukan pendidikan karakter di sekolah.

Manfaat dari pembelajaran Number Head Together (NHT) yang dilaksanakan di kelas XI UPW SMK Negeri 1 Kota Bima yaitu :

1. Semua siswa dan siswi menjadi lebih siap dalam belajar

2. Siswa akan berdiskusi dengan sungguhsungguh

3. Hasil belajar akademik struktural bertujuan untuk meningkatkan kinerja siswa dalam tugas- tugas akademik.

4. Pengakuan adanya keberagaman, ini bertujuan agar siswa dapat menerima teman- temannya yang mempunyai berbagai latar belakang.

5. Pengembangan keterampilan sosial, ini bertujuan untuk mengembangkan keterampilan sosial siswa. Keterampilan yang di maksud antara lain berbagai tugas, aktif bertanya, menghargai pendapat orang lain, mau menjelaskan ide atau pendapat, bekerja sama dalam kelompok dan sebagainnya.

6. Pemahaman siswa lebih mendalam, meningkatkan kebaikan budi pekerti,kepekaan dan toleransi serta hasil belajar lebih tinggi.
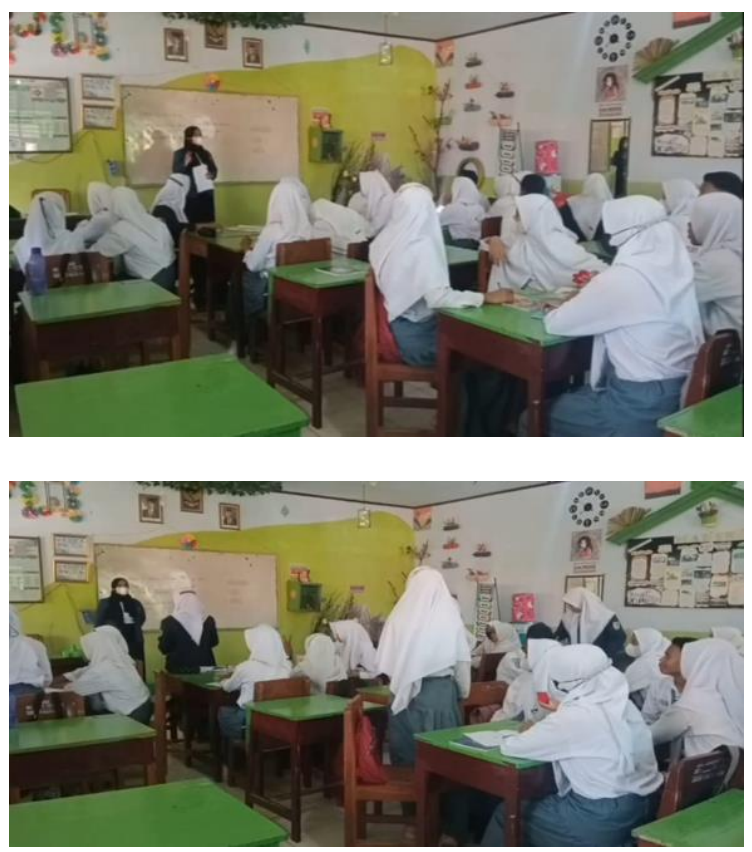

Gambar 1. Pelaksanaan Metode Pembelajaran NHT pada Kelas XI UPW

\section{Pembentukan Pendidikan Karakter dalam Menumbuhkan Sikap Demokratis Siswa Melalui Kegiatan di Luar Pembelajaran.}

Selain melalui kegiatan pembelajaran pembentukan pendidikan karakter dalam menumbuhkan sikap demokrasi juga dapat dilakukan di luar kegiatan pembelajaran, diantaranya melalui Budaya Sekolah. Budaya yang dilakukan di SMK Negeri 1 Kota Bima sangatlah beragam dan tentunya positif guna mengembangkan dan membina karakter siswanya. Budaya Sekolah tersebut diantaranya, yaitu:

\section{Budaya Sekolah Sebelum Kegiatan Pembelajaran di Mulai}

Dalam hal ini pada kegiatan sebelum pembelajaran terdapat aturan yaitu seluruh warga sekolah menjalankan Kegiatan Religi yang dilakukan pada pukul 07.00 kegiatan tersebut wajib di lakukan oleh seluruh warga sekolah, mengingat sudah termonitor dan terpantau secara langsung dari pusat informasi audio. Kegiatan tersebut tentu dilakukan sebagai langkah preventif guna membentuk Pendidikan Karakter pada siswa, dimana siswa selalu ingat kepada Tuhan melalui kegiatan Religi (berdoa bersama). Pemberian hukuman terhadap siswa yang terlambat masuk sekolah juga dilakukan dengan trigment yang mendidik yaitu apabila siswa yang terlambat masuk sekolah nantinya akan dihukum yaitu berdiri di depan tiang bendera. Pemberian hukuman tersebut berpijak pada rasa nasionalisme siswa, karena guru berdalih ketika siswa terlambat maka mereka pasti tidak mengikuti kegiatan religi Oleh karena itu, hukuman yang diberikan tidak jauh beda dengan apa yang sudah siswa langgar dan tentunya tetap mendidik dan memberikan nilai tersendiri terhadap siswa.

\section{Budaya Sekolah dalam Kegiatan Organisasi Siswa}

Organisasi Siswa yang ada di SMK Negeri 1 Kota Bima memiliki banyak kegiatan yang bersifat penguatan nilai-nilai karakter dan mampu menjadi wadah bagi siswa dalam mengaktualiasasikan bakat dan minta yang dimiliki oleh siswa. Kegiatan organisasi ini tentu memiliki budaya yang terapkan di dalamnya, salah satunya dalam pemilihan Ketua OSIS menggunakan sistem Pemilihan Umum. Sistem tersebut mengadopsi dari sistem pemilihan presiden dan wakil presiden di Indonesia yang dilakukan dengan cara memilih 
langsung calon dan dilakukan penghitungan secara langsung setelahnya.

Kegiatan tersebut tentu sangat membantu untuk membangun karakter siswa dan tentunya sebagai salah satu bentuk implementasi nilai demokratis yang ada di sekolah. Selain itu kegiatan tersebut mampu membangun kesadaran siswa terhadap hak suara yang dimiliki oleh masingmasing individu. Karena hak suara tidak hanya dimiliki siswa sebagai warga sekolah tetapi usia SMK sebagian juga sudah memiliki hak suara dalam kegiatan pemilihan umum di Indonesia baik pemilihan presidan maupun pemilihan legislatif.

\section{Budaya Musyawarah dalam Setiap Pengambilan Keputusan atau Kebijakan}

Musyawarah adalah bentuk implementasi nyata sikap demokratis yang selalu dipengang oleh SMK Negeri 1 Kota Bima untuk diterapkan musyawarah dalam berbagai pengambilan keputusan maupun kebijakan sekolah. Dimulai dari hal sederhana membiasakan siswa untuk musyawarah dalam pembentukan struktur organisasi kelas.

Kemudian beranjak pada musyawarah yang memilki jangkauan lebih luas yaitu ketika hendak mengadakan kegiatan Study Tour. Ini di khususkan bagi jurusan UPW

(Usaha Perjalanan Wisata). Sekolah memberikan angket dan dibagikan kepada seluruh calon peserta study tour guna untuk memilih dan memberikan saran terkait destinasi yang nantinya akan di kunjungi. Hal ini merupakan salah satu bentuk fasilitas yang diberikan oleh sekolah terhadap siswa untuk menyalurkan aspirasinya dan siswa ikut terlibat dalam pemilihan kebijakan sekolah. Nilai yang dapat dipetik dalam kegiatan tersebut yaitu budaya bermusyawarah melalui angket. Hasil dari angket tersebut nanti akan di akumulasikan dan kemudian dijadikan sebagai bahan pertimbangan dalam memilih keputusan.

Pengambilan kebijakan sekolah tentu bukan hanya siswa saja yang di perhatikan, orang tua siswa juga turut andil dalam pembuatan kebijakan. Misalnya, dalam pengambilan keputusan pada kegiatan Study Tour wali murid akan diberikan angket untuk diisi apakah menyetujui siswa untuk mengikuti kegiatan tersebut atau tidak. Jika memang orang tua tidak berkenan, maka pihak sekolah tidak memaksa apalagi mewajibkan siswa untuk ikut. Bagi siswa yang orang tuanya tidak mengizinkan akan tetap masuk sekolah selama kegiatan Study Tour berlangsung, dan mendapatkan pembelajaran yang diisi oleh bimbel yang sudah bekerja sama untuk memberikan bimbingan belajar selama guru kelas yang bersangkutan mendampingi kegiatan Study Tour.

Salah satu tipe dari model pembelajaran kooperatif adalah Number Head Together (NHT). Teknik Belajar atau model pembelajaran Number head together (NHT) dikembangkan oleh Spencer Kagan (1992). Model ini dapat digunakan untuk semua mata pelajaran dan semua tingkatan peserta didik.

Menurut Ibrahim (2000:28) Model Pembelajaran kooperatif tipe Numbered Head Together (NHT) memiliki unsur-unsur model belajar mengajar yaitu:

a. Sintaks

Adapun Sintak atau Langkah-langkah Model Pembelajaran Numbered Head Together (NHT) adalah sebagai berikut

1. Pendahuluan

Pada pendahuluan berisi tettang persiapan antara lain:

a.Guru menjelaskan tentang pembelajaran kooperatif tipe Numbered Heads Together (NHT).

b. Guru menyampaikan tujuan pembelajaran c.Guru melakukan apersepsi

d. Guru memberikan motivasi pada siswa

2. Kegiatan Inti

Kegiatan inti adalah pelaksanaan pembelajara kooperatif tipe Numbered Head Together (NHT).

Fase 1 : Penomoran Penomoran Guru membagi siswa dalam kelompok beranggotakan 4-5 orang dan kepada setiap anggota kelompok diberi nomor antara 1 sampai 5.

Fase 2 : Mengajukan pertanyaan : Guru mengajukan sebuah pertanyaan kepada siswa. Dalam hal ini guru memberikan pertanyan berupa lembar kerja siswa (LKS).

Fase 3 : Berfikir bersama : Siswa berfikir bersama menyatukan pendapatnya terhadap jawaban pertanyaan yang berupa LKS dan meyakinkan tiap anggota dalam timnya mengetahui jawaban itu.

Fase 4 : Menjawab Menjawab : Guru memanggil satu nomor tertentu, kemudian siswa yang 
nomornya sesuai mengacungkan tangannya dan mencoba menjawab pertanyaan di depan kelas.

3. Penutup Penutup merupakan tahap evaluasi.

a. Dengan bimbingan guru siswa membuat kesimpulan.

b. Siswa diberi PR dari buku paket atau buku panduan lain.

\section{b. Sistem Sosial}

Sistem sosial yang berlaku dalam model pembelajaran kooperatif tipe Numbered Head Togerther (NHT) adalah: Siswa diberi pengarahan untuk berdiskusi bersama kelompoknya. Siswa bebas untuk mengemukakan pendapatnya, mengajukan pertanyaan dan menjawab pertanyaan.

\section{c. Prinsip Reaksi}

Prinsip reaksi model pembelajran kooperatif tipe Numbered Head Together (NHT) adalah: Guru menjelaskan tentang cara pembelajaran yang akan dilaksanakan. Guru membagi siwa dalam bentuk kelompok. Setiap kelompok terdiri dari empat sampai lima orang siswa dan setiap kelompok mendapat nomor yang berbeda. Guru menyampaikan materi pembelajaran Guru memberikan pertanyaan yang berupa LKS. Guru memberikan pengarahan siswa untuk berdiskusi dalam kelompok guna menyelesaikan permasalahan. Guru menunjuk salah satu nomor siswa secara acak untuk menjawab pertanyaan di depan kelas.

Jadi, dalam penerapan Model Pembelajaran Numbered Head Together (NHT), siswa dibagi menjadi beberapa kelompok dan setiap anggota kelompok diberi nomor kepala. Selanjutnya di ssetiap kelompok dilakukan diskusi untuk menjawab permasalahan atau untuk melakukan suatu kegiatan. Dari hasil kegiatan tersebut guru mengundi nama kelompok dan nomor anggota kelompok yang harus menjawab pertanyaan atau mempresentasikan kegiatan. Berkaitan dengan hal ini, maka setiap anggota kelompok dituntut untuk bekerja sama karena jawaban atau presentasi dari perwakilan anggota kelompok akan menjadi generalisasi kemampuan atau nilai kelompok.

\section{Kesimpulan}

Pendidikan karakter bertujuan untuk kembali menghidupkan karakter warga negara yang sesuai dengan nilai-nilai Pancasila, antara lain nilai ketaqwaan, nilai keimanan, nilai kejujuran, nilai kepedulian, hingga nilai etika atau sopan santun. Dalam mata pelajaran Pendidikan Pancasila dan Kewarganegaraan merupakan salah satu sarana yang tepat untuk mengimplementasikan nilai-nilai dalam pendidikan karakter demokratis kepada peserta didik, karena tujuan PPKn pada dasarnya adalah untuk menciptakan peserta didik menjadi warga negara yang demokratis dan berkarakter sesuai dengan nilai-nilai Pancasila.

\section{Ucapan Terima Kasih}

Terima kasih kepada Dosen Pembimbing Lapangan Bapak Ahmad Fauzan S.Pd, M.Pd yang telah memberikan arahan, bimbingan, serta motivasi dalam pelaksanaan PLP FKIP, Universitas Mataram di SMK Negeri 1 Kota Bima. Ucapan terima kasih juga kami sampaikan kepada Kepala SMK Negeri 1 Kota Bima Ibu Ratnah S.Pi., M.Pd, Guru Pamong Bapak Drs. Mahardin dan seluruh komponen yang ada di SMK Negeri 1 Kota Bima yang telah membantu kami dalam menyelesaikan kegiatan ini dengan baik dari awal hingga akhir.

\section{Daftar Pustaka}

Ilham Muhammad, W. I. A. (2018). Nilai pendidikan karakter demokratis dan toleransi dalam novel karya habiburahman el shirazy dan relevansinya dengan pembelajaran sastra. Jurnal Bahasa, 7(4), $1-10$.

Juliardi, B. (n.d.). Implementasi pendidikan karakter melalui pendidikan kewarganegaraan. 119-126.

Saputri Isnaini, S. R. N. (n.d.). Strategi Orang Tua Dalama Pempembetukan Karakter Demokratis Siswa Putus Sekolah Di Wilayah Pesisir Pantai Klayar Lamongan. 1704025408, 243-257. 